\title{
Light reductions drive macroinvertebrate changes in Amphibolis griffithii seagrass habitat
}

\author{
A. Gartner $^{1, *}$, P. S. Lavery ${ }^{1}$, K. McMahon ${ }^{1}$, A. Brearley ${ }^{2}$, H. Barwick ${ }^{1}$ \\ ${ }^{1}$ Coastal Marine Ecosystems Research Group, Faculty of Communications, Health and Science, Edith Cowan University, \\ Joondalup 6027, Western Australia \\ ${ }^{2}$ School of Plant Biology, Faculty of Natural and Agricultural Sciences, The University of Western Australia, Crawley 6009, \\ Western Australia
}

\begin{abstract}
Numerous anthropogenic activities can significantly reduce the amount of light reaching seagrass habitats. Typically these result in morphological and physiological changes to the plant and associated algal epiphytes. However, the flow-on effects to seagrass-dependent fauna induced by these disturbances has yet to be examined. This study investigated the effects of different light reduction intensity (high: $\sim 92 \%$ reduction; moderate: $\sim 84 \%$ reduction), duration $(3,6$ and 9 mo) and timing (post-winter and post-summer) on the density and biomass of macroinvertebrate epifauna within an Amphibolis griffithii seagrass ecosystem (Western Australia). There were generally lower epifauna densities and biomass within shaded seagrass plots. When moderate intensity shading was imposed at the end of winter, total density in unshaded controls was $31 \%$ lower at $3 \mathrm{mo}$, and $78 \%$ lower at 9 mo. When high intensity shading was imposed, total density was $38 \%$ lower than in controls at 3 mo, and $89 \%$ lower by 9 mo. Although densities varied, similar magnitudes of decline occurred in post-summer shaded treatments. Taxa-specific responses were variable in terms of time, rapidity and magnitude of response. Amphipod, isopod and gastropod densities generally declined in response to shading. Bivalve densities declined with shading post-summer, but not post-winter. Ostracod densities had an inconsistent response to moderate shading. Changes in epifaunal density were largely associated with declines in algal biomass, leaf variables and stem biomass, indicating food and habitat limitations. It is likely that the significant declines in epifauna observed in this experiment would have flow-on consequences to higher trophic levels.
\end{abstract}

KEY WORDS: Seagrass · Disturbance $\cdot$ Shading $\cdot$ Western Australia Resale or republication not permitted without written consent of the publisher

\section{INTRODUCTION}

Seagrass fauna assemblages play an integral functional role, particularly in their capacity for converting the primary production of seagrass and algae into secondary production (Jernakoff et al. 1996) which is then available to higher trophic levels (Klumpp et al. 1989, Edgar 1990a). Being a near-shore habitat, seagrass systems are susceptible to a variety of anthropogenic pressures (Short \& Wyllie Echeverria 1996, Bostrom et al. 2006, Orth et al. 2006) including reduced light availability. Significant causes of light reduction include eutrophication (Baden et al. 2003), sedimentation, and dredging activities (Sheridan 2004). Reductions in the availability of light for photosynthesis are a major cause of seagrass loss or decline (Short \& Wyllie Echeverria 1996, Longstaff \& Dennison 1999, Orth et al. 2006), the effects of which are likely to flow through to higher trophic levels.

Typical seagrass responses to light reduction include decreases in carbohydrate content, shoot density, number of leaves and shoot productivity (West 1990, Ruiz \& Romero 2001, Cabello-Pasini et al. 2002), which can lead to seagrass loss or changes in canopy structure (Lavery et al. 2009). Given the link between seagrass systems as a provider of food and habitat to sec- 
ondary production (Jernakoff et al. 1996, Bostrom et al. 2006), it could be expected that the effects of changes in seagrass would flow through to higher trophic orders. The abundance and composition of epifauna, especially those associated with the leaves (Edgar \& Robertson 1992), are likely to be affected once the morphology of the seagrass canopy begins to change. Despite this important implication, the vast majority of research in seagrass decline has focused on the primary producers. Only 2 studies have experimentally examined epifauna response to light reduction in a seagrass system (Edgar 1990b, Edgar \& Robertson 1992); both of these studies found reductions in the abundance of epifauna in treatments subjected to dark conditions. The changes were explained by a reduction in algal epiphytes, which are a key food source for many epifauna (Jernakoff et al. 1996, Jernakoff \& Nielsen 1997). There appears to have been no further attempts to examine the implications of light reduction on epifauna in seagrass meadows, especially in the context of human induced disturbance to seagrass systems.

There are many anthropogenic pressures, such as eutrophication, sedimentation and dredging, which magnify variations in light availability to benthic systems. Recent experiences, where significant loss of seagrass occurred as a result of dredging (EPA 2002, Erftemeijer 2006), have highlighted a current lack of understanding on how light limitations on seagrass meadows affect associated fauna; in particular, the indirect effects of turbid plumes caused by the suspension of sediments in the water column through dredging (EPA 2002). The light available to seagrass (and epiphytic algae) varies greatly with the seasons and weather, both of which influence the intensity, wavelength, photoperiod and duration of the light climate. Consequently, seagrasses are adapted to variable light conditions and have evolved strategies to cope with reductions in photosynthetic photon flux density (PPFD) within natural limits. However, most studies on the effect of reduced PPFD have been simple, when in fact the response is likely to reflect complex interactions of the intensity, duration and time of light reduction (Lavery et al. 2009).

Recently, field manipulations of light intensity, applied for 3 different durations at the end of the summer and winter seasons, have been shown to affect potential food resources for macroinvertebrates (e.g. algal epiphyte biomass) and the structural complexity of seagrass habitats (Lavery et al. 2009). The changes to seagrass habitat induced by this study offered the opportunity to assess the effects of changing seagrass habitat on first order consumers in terms of complex patterns in PPFD. We assess the effects and trophic implications of changes to primary producer habitats resulting from reduced light conditions for the epibenthic macroinvertebrate fauna (hereafter referred to as 'epifauna'), focusing in this instance on Amphibolis griffithii seagrass ecosystems. In particular, we compared the epifauna density and biomass for seagrass meadows of differing shading intensity (unshaded, moderate, and high), under conditions of different light duration and timing. Based on this design, we attempted to evaluate the prediction that disturbances induced by shading treatments will lead to declines in epifauna density and biomass, as a consequence of a reduction in food and habitat resources. As part of this investigation, we developed a multiple linear regression model to test for relationships between epifauna density and changes in seagrass habitat. We also undertook multivariate analysis to explore responses in the epifauna assemblage composition, as well as faunal recovery post shading (these analyses will be reported separately).

\section{MATERIALS AND METHODS}

The study was conducted at Jurien Bay, $260 \mathrm{~km}$ north of Perth, Western Australia. The near-shore Jurien Bay region, considered to be near-pristine (EPA 2001), is dominated by seagrass, sand and macro-algal reef habitats. The study site was located in an extensive mono-specific Amphibolis griffithii seagrass bed of approximately $5.0 \mathrm{~m}$ depth, $300 \mathrm{~m}$ north-east of Boullanger Island $\left(30^{\circ} 18^{\prime} 34^{\prime \prime} \mathrm{S}, 115^{\circ} 00^{\prime} 26^{\prime \prime} \mathrm{E}\right.$ - WGS 84 datum). Mean water temperatures ranged between $18.7^{\circ} \mathrm{C}$ in December to $21.7^{\circ} \mathrm{C}$ in June. Jurien Bay has a mean tidal range of $0.5 \mathrm{~m}$ (Holloway 2006), meaning that seagrass at the experimental site was completely submerged year-round. Water circulation in summer is dominated by the effect of the diurnal sea breeze, while circulation in winter is influenced by the passing of winter storms (Holloway 2006).

A 'shading experiment' was undertaken to examine the response of Amphibolis griffithii and associated algal epiphytes to changes in shading intensity, for different durations and with commencement at 2 different times (Lavery et al. 2009). These treatments induced changes in seagrass biomass, morphology and associated algal epiphytes (structural complexity) which constitute the treatments used to examine the flow-on effects to epifauna (Lavery et al. 2009). Therefore, we explicitly tested the effects of light-induced changes to seagrass meadows on epifauna and not the effects of shading per se.

While the shading experiment provided conditions to which seagrasses responded, it also had the potential for confounding the epifaunal response. The main concerns were that epifauna responded to the pres- 
ence of the shade structures rather than changes in seagrasses, or to an observed increase in fish abundance under the shade screens which could alter predation pressure. To address these issues, a 'structural complexity reduction experiment' and a 'caging experiment' were conducted separately to examine the effect of these potentially confounding factors on seagrass epifauna.

Shading experiment. The shading experiment was established with 3 main factors: Intensity (high, moderate or control), Duration (3, 6 or $9 \mathrm{mo}$ ) and Time (postwinter and post-summer) of light reduction (Table 1). The light reductions and durations of the experiment reflected those typically resulting from dredging programmes in the region (McMahon \& Lavery 2008). The timing for levels of light reduction coincided with presumed resilience of the seagrass to the effects of shading (Carruthers \& Walker 1997). Post-summer treatments ran from January to November 2005; post-winter treatments ran from December 2005 to July 2006. Temperature, light and other conditions varied more among durations than between times (Table 1). No extreme climatic events occurred at the study site during the course of the experiment. Five replicate plots were established for each combination of intensity, duration and time, yielding an orthogonal design with 90 experimental units (hereafter referred to as plots).
Each plot measured $4.5 \times 3.0 \mathrm{~m}$, with light reduction treatments comprising a screen of commercial shade cloth (high density woven polyethylene) representing 'high intensity' (woven at $80 \%$ density), 'moderate intensity' (woven at $50 \%$ density) and 'controls' (no shade cloth); these were suspended above the meadow on plastic frames approximately $0.4 \mathrm{~m}$ above the seagrass canopy and $1.5 \mathrm{~m}$ above the sediment floor. Plots were randomly set in a grid system with a minimum of 1 frame length between plots in rows $(\sim 4.5 \mathrm{~m})$, and 1 frame width between rows $(\sim 3 \mathrm{~m})$. PPFD intensity ( $\mu \mathrm{mol}$ quanta $\mathrm{m}^{-2} \mathrm{~s}^{-1}$ ) was recorded at the top of the canopy in randomly chosen control and treatment plots at 15 min intervals using 'Odyssey Dataflow' submersible incident light sensors with an automated wiper unit (Carruthers et al. 2001). The shade cloth induced an 81 to $87 \%$ PPFD reduction (total irradiance) in the moderate treatments, and an 89 to $95 \%$ reduction in the high treatments. Thus, canopy shaded at the end of summer were entering a period of declining PPFD but relatively warm temperature, while those shaded post-winter were entering a period of increasing PPFD but relatively low temperature. The experimental design established treatments that consistently varied in light intensity rather than attempting to establish absolute light reduction, which would have been too difficult to control (Lavery et al. 2009).

Table 1. Amphibolis griffithii. Mean biomass $( \pm$ SE) of leaves, stem, algal epiphytes and stem and leaf cluster density following photosynthetic photon flux density (PPFD) reduction treatments of timing: post-summer, post-winter; duration: 3, 6, 9 mo; and intensity: control, moderate, high. All data $n=5$. Dates refer to sample collection times. Water temp.: the mean over the treatment duration (Lavery et al. 2009); DW: dry weight

\begin{tabular}{|c|c|c|c|c|c|c|c|c|}
\hline $\begin{array}{l}\text { Duration \& } \\
\text { timing }\end{array}$ & Intensity & $\begin{array}{c}\text { Leaf } \\
\text { biomass } \\
\left(\mathrm{g} \mathrm{DW} \mathrm{m}^{-2}\right)\end{array}$ & $\begin{array}{c}\text { Algal } \\
\text { epiphyte } \\
\text { biomass } \\
\left(g \mathrm{DW} \mathrm{m}^{-2}\right)\end{array}$ & 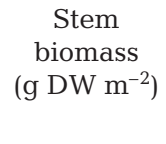 & $\begin{array}{c}\text { No. of } \\
\text { stems with } \\
\text { leaves } \\
\left(\mathrm{m}^{-2}\right)\end{array}$ & $\begin{array}{l}\text { Leaf } \\
\text { cluster } \\
\text { density } \\
\left(\mathrm{m}^{-2}\right)\end{array}$ & $\begin{array}{l}\text { Water } \\
\text { temp. } \\
\left({ }^{\circ} \mathrm{C}\right)\end{array}$ & $\begin{array}{c}\text { Avg. } \\
\text { instant. } \\
\text { PPFD } \\
\left(\mu \mathrm{mol} \mathrm{m}^{-2} \mathrm{~s}^{-1}\right)\end{array}$ \\
\hline \multicolumn{9}{|l|}{ Post-summer } \\
\hline $3 \mathrm{mo}$ & Control & $257 \pm 68$ & $112 \pm 35$ & $175 \pm 50$ & $276 \pm 69$ & $3500 \pm 785$ & 21.7 & 218 \\
\hline \multirow[t]{2}{*}{ June 2005} & Moderate & $111 \pm 21$ & $24 \pm 9$ & $132 \pm 23$ & $248 \pm 24$ & $2632 \pm 374$ & & 35 \\
\hline & High & $71 \pm 17$ & $28 \pm 19$ & $116 \pm 25$ & $224 \pm 55$ & $1984 \pm 474$ & & 11 \\
\hline $6 \mathrm{mo}$ & Control & $222 \pm 41$ & $260 \pm 44$ & $164 \pm 39$ & $253 \pm 26$ & $2941 \pm 640$ & 20.0 & 191 \\
\hline \multirow[t]{2}{*}{ September 2005} & Moderate & $39 \pm 9$ & $25 \pm 6$ & $174 \pm 16$ & $267 \pm 29$ & $1484 \pm 376$ & & 31 \\
\hline & High & $9 \pm 4$ & $12 \pm 5$ & $119 \pm 17$ & $155 \pm 31$ & $563 \pm 239$ & & 12 \\
\hline $9 \mathrm{mo}$ & Control & $213 \pm 18$ & $179 \pm 46$ & $195 \pm 28$ & $364 \pm 36$ & $4208 \pm 394$ & 19.6 & 277 \\
\hline \multirow[t]{2}{*}{ November 2005} & Moderate & $2 \pm 2$ & $57 \pm 17$ & $142 \pm 21$ & $44 \pm 25$ & $52 \pm 47$ & & 52 \\
\hline & High & $0 \pm 0$ & $19 \pm 4$ & $90 \pm 22$ & $36 \pm 16$ & $8 \pm 5$ & & 27 \\
\hline \multicolumn{9}{|l|}{ Post-winter } \\
\hline $3 \mathrm{mo}$ & Control & $207 \pm 17$ & $204 \pm 18$ & $173 \pm 35$ & $328 \pm 73$ & $4724 \pm 1153$ & 18.7 & 508 \\
\hline \multirow[t]{2}{*}{ December 2005} & Moderate & $205 \pm 11$ & $106 \pm 13$ & $207 \pm 21$ & $356 \pm 16$ & $5256 \pm 574$ & & 93 \\
\hline & High & $70 \pm 2$ & $65 \pm 5$ & $83 \pm 6$ & $196 \pm 21$ & $1988 \pm 106$ & & 59 \\
\hline $6 \mathrm{mo}$ & Control & $176 \pm 17$ & $123 \pm 8$ & $159 \pm 27$ & $200 \pm 30$ & $2960 \pm 735$ & 19.9 & 481 \\
\hline \multirow[t]{2}{*}{ March 2006} & Moderate & $34 \pm 0.99$ & $65 \pm 7$ & $104 \pm 11$ & $140 \pm 9$ & $1116 \pm 72$ & & 68 \\
\hline & High & $9 \pm 1$ & $26 \pm 2$ & $120 \pm 14$ & $108 \pm 14$ & $504 \pm 149$ & & 39 \\
\hline $9 \mathrm{mo}$ & Control & $190 \pm 18$ & $176 \pm 31$ & $183 \pm 15$ & $252 \pm 19$ & $2464 \pm 137$ & 19.8 & 383 \\
\hline \multirow[t]{2}{*}{ July 2006} & Moderate & $13 \pm 5$ & $33 \pm 10$ & $112 \pm 17$ & $136 \pm 35$ & $496 \pm 116$ & & 51 \\
\hline & High & $0.3 \pm 0.2$ & $20 \pm 8.4$ & $104 \pm 23$ & $40 \pm 26$ & $24 \pm 15$ & & 29 \\
\hline
\end{tabular}


To maintain these treatments, shade cloths were replaced every 2 to $6 \mathrm{wk}$ to minimize fouling from algae.

The induced disturbance to the seagrass canopy from the light reduction treatments is fully reported by Lavery et al. (2009). In summary, the treatments largely resulted in loss of seagrass leaves and algal epiphytes (Table 1). For post-summer, both the moderate and high intensity treatments had significantly fewer leaves compared to the controls after $3 \mathrm{mo}$, but there was no significant difference between moderate and high for any of the duration treatments $(3,6,9 \mathrm{mo})$. For post-winter, there was no effect on the leaf biomass in the moderate treatment after $3 \mathrm{mo}$, but there was a decline in the high treatment. Trends at 6 and 9 mo post-winter were similar to postsummer. Trends in algal epiphyte biomass were similar to changes in the seagrass leaf canopy, with the exception of the post-winter moderate intensity treatment at $3 \mathrm{mo}$, where biomass was significantly lower than in controls (Table 1).

Epifauna samples were collected from each plot by lowering a calico bag (finely woven unbleached cotton, mesh size $<0.5 \mathrm{~mm}$ ) with $0.04 \mathrm{~m}^{-2}$ quadrat onto the seagrass canopy, cutting the seagrass stems at the base of the sediment and then closing the calico bag to retain the mobile fauna within (Brearley \& Wells 2000, Brearley et al. 2008). Two samples were collected at every sampling occasion and combined for fauna analysis. Epifauna were sorted, counted and sized into identifiable taxonomic units to class/order level under a dissecting microscope. Within each taxonomic unit, the size of each individual was determined (ca. $\geq 0.5,0.7,1.0,1.4,2.0,2.8,4.0$, or $5.6 \mathrm{~mm}$ in length). For the above sizes, the ash free dry weight biomass (AFDW) was calculated using the biomass regressions of Edgar (1990c).

The very few larger individuals $(\geq 0.8 \mathrm{~mm})$ found in samples included asteroids, polychaetes, and colonial ascidians. These large individuals were excluded from the study, primarily because the scale at which samples were collected $\left(0.04 \mathrm{~m}^{-2}\right.$ quadrats) was ineffective for capturing large individuals and did not provide a reasonable representation of their density. They also appeared to mask differences in the biomass of smaller, more common, taxa.

The effects of changes in seagrass structure on total epifauna density and biomass induced by the intensity, duration and timing of shading were tested by a 3-Factor ANOVA using Statistica (Version 7.0, StatSoft), with all main effects treated as fixed factors. We also tested for effects on the density and biomass for the 5 most common taxa (gastropods, amphipods, isopods, ostracods and bivalves). Transformations were applied where data did not conform to the underlying assumptions of ANOVA (Quinn \& Keough 2002). Where ANOVA yielded significant effects, Fisher's least square differ- ence (LSD) post-hoc comparison tests were used to specify where the differences among treatments lay.

Relationships between seagrass habitat variables and epifaunal density were tested using a multiple regression model constructed in Statistica. Data from plots shaded for 9 mo were used; these included the greatest differences in seagrass attributes among the control, moderate and high intensity shading treatments. Where seagrass and algal epiphyte variables were co-correlated (e.g. seagrass leaf biomass and the number of seagrass leaves), the factor(s) with the lowest correlation was removed (tolerance, $1-\mathrm{R}^{2}<0.1$ ) as their presence posed a threat to the validity of multiple regression analysis (Field 2005).

Structural complexity and reduction experiment. An experiment was undertaken to confirm that effects in the shading experiment were due, at least in part, to changes in seagrass structural complexity resulting from the treatments, rather than being a response to the presence of the shade screens. Epifauna density was compared in control (natural complexity) and reduced structural complexity treatments. Reduced structure mimicked the seagrass structural attributes observed after 6 mo of shading at high light reduction in the main shading experiment (i.e. loss of leaves and algal epiphytic algae). In these treatments, $\sim 50 \%$ of leaf clusters were cut off (leaving only $\sim 6$ clusters per stem remaining); $\sim 50 \%$ of algal epiphytes were removed (by hand) in replicate Amphibolis griffithii plots at the study site. All stems were retained. Procedural controls were created by physically agitating seagrass by hand for $1 \mathrm{~min}$ to replicate the disturbance experienced by the treatment plots during establishment. Control plots were not disturbed. Plots were $1.0 \mathrm{~m}^{2}$ and marked by corner stakes and flagging tape. Using methods described previously, epifauna samples were collected after $1 \mathrm{mo}$, a duration considered appropriate for epifaunal re-colonization following disturbance during construction (Jernakoff \& Nielsen 1997).

Five replicate plots were constructed for each treatment, giving 15 experimental units in total. However, 2 'reduced structure' samples had to be discarded due to diver error in the collection of samples outside plot boundaries, giving an unbalanced statistical design. Differences in total epifaunal density were tested using 1-way ANOVA (fixed factor) as described previously, but using a reduction in degrees of freedom (residual $\mathrm{df}=10$ ) to account for the missing samples (Zar 1999).

Caging experiment. Carnivorous or omnivorous fish are the main predators of motile epifauna in seagrass meadows (Klumpp et al. 1989, Jernakoff et al. 1996). Herbivorous fish consume the epiphytic algae found on seagrasses (Jernakoff et al. 1996), and may also incidentally ingest small quantities of the host seagrasses and fauna. The primary shading experiment 
used shade cloth to create different light intensities in the moderate and high intensity treatments; this may have inadvertently created an artificial habitat favored by fish species, some of which may prey on epifauna.

To test this hypothesis, video surveys were carried out in May 2006 over a $2 \mathrm{~d}$ period to quantify fish abundances under shade cloths in the main shading experiment. Each shading treatment (control, moderate and high) had 4 replicates, yielding 12 experimental units in total. Recordings were made for $15 \mathrm{~min}$ at each plot. Maximum fish abundance was determined as the maximum number of fish over any $1 \mathrm{~min}$ period. This provided a consistent relative measure between treatments. One-way ANOVA confirmed that the presence of shade cloths had an effect on fish abundance ( $\mathrm{df}=2$, $F=7.07, \mathrm{p}=0.01$ ). Post hoc analysis revealed significantly higher numbers of fish in the moderate (18.5 \pm $2.7)$ and high $(46 \pm 6.4)$ intensity treatments compared to the control $(5.2 \pm 2.1)$, but no significant difference between moderate and high intensity treatments. Fish species observed under shade cloths included omnivorous (Pelsartia humeralis, Pelates sexlineatus, Torquigener pleurogramma, Scobinichthys granulatus), carnivorous (Pentapodus vitta, Sphyraena obtusata, Psammoperca waigiensis) and invertivorous species (Apogon rueppellii, Enoplosus armatus, Apogon victoriae, Pempheris klunzingeri, Coris auricularis).

To determine the influence of increased fish abundances under the shaded treatments as a confounding factor, we tested the hypothesis that greater abundances of fish under shaded treatments would lead to increased predation pressure and result in lower epifaunal densities. The caging experiment was designed to examine 2 main factors: Shade Cloth (present or absent) and Caging (cage closed, cage open and open). Four $4.5 \times$ $3.0 \mathrm{~m}$ replicates of each treatment were established (as per the shading experiment using $50 \%$ shade cloth), yielding 24 experimental units in total, randomly located alongside the primary shading experiment.

Cages $\left(1.0 \mathrm{~m}^{3}\right)$ were constructed from polyethylene mesh (10 $\mathrm{mm}$ aperture). This mesh size permitted the movement of epifauna through the seagrass canopy, but prevented access by larger fish aggregating under shade cloths. The mesh was attached to metal pickets and secured with cable ties to form $1 \mathrm{~m}^{3}$ cubes. To account for cage effects (Edgar 1990b), 'cage open' cages were deployed with 1 side open to allow access by predators. Open plots were simply pegged to form $1 \mathrm{~m}^{2}$ plots and marked with flagging tape. Epifauna samples were collected as per the shading experiment.

The experiment treatments were deployed for $18 \mathrm{~d}$ (long enough to determine the effects of predation, but not for shade cloths to affect seagrass canopy). Diver observations noted fish congregations under the shade cloths immediately after deployment.
Differences in total epifaunal density among treatments were tested using a 2-factor ANOVA, with all main effects (shade cloth and cages) treated as fixed factors. The 5 main taxa groups (gastropods, amphipods, isopods, ostracods and bivalves) were also examined separately, in line with the shading experiment. Data were summarized and transformed, and post-hoc tests carried out as previously described.

\section{RESULTS}

\section{Total epifauna response to shading treatments}

Faunal density was 31 to $89 \%$ lower in the shaded seagrass treatments compared to the unshaded controls (Fig. 1), with the effect of intensity of shading dependent on the duration $(I \times D, p<0.01)$ and the effect of duration of shading dependent on time $(\mathrm{D} \times \mathrm{T}$, $\mathrm{p}<0.01$ : Table 2). Due to the significant interaction terms, differences in densities among intensities were examined for each duration at each time (Fig. 1). In post-summer, high intensity shaded treatments had $\sim 71 \%$ fewer individuals than controls after $3 \mathrm{mo}$; there was no effect of moderate shading until $6 \mathrm{mo}$, at which time there were $41 \%$ fewer individuals than in the control. There was also a $72 \%$ difference in density in moderate and high treatments at 3 mo. In the post-winter treatments, epifaunal densities in both moderate and high intensity shaded treatments were significantly lower than in controls by 6 mo (by $63 \%$ and $77 \%$ respectively), but were not different to each other. After 9 mo of shading (regardless of time), epifaunal densities in both moderate and high intensity shading treatments were significantly lower than in unshaded control treatments (by $78 \%$ and $89 \%$ respectively).

The 3 main factors of Intensity, Duration and Time of light reduction all had a significant effect on total biomass; however, there was no interaction between these factors (Table 2). Epifaunal biomass was much greater post-winter than post-summer (Fig. 1c,d). There were also differences among durations, however, no obvious trend. Among intensities, high intensity treatments had significantly lower biomass than both moderate and control treatments, which did not differ from each other (Fisher's post-hoc LSD, p < $0.01)$.

The dissimilar effects of the treatments on fauna density and biomass were reflected in the size class distribution of taxa (Fig. 2). The density of fauna at 3 mo was dominated by small organisms $(\leq 1.4 \mathrm{~mm})$ while biomass was dominated by fewer large organisms (>1.4 mm: Fig. 2a-d). This trend was most obvious in the highly shaded treatments. There were also other trends among intensities: on a relative basis, the 

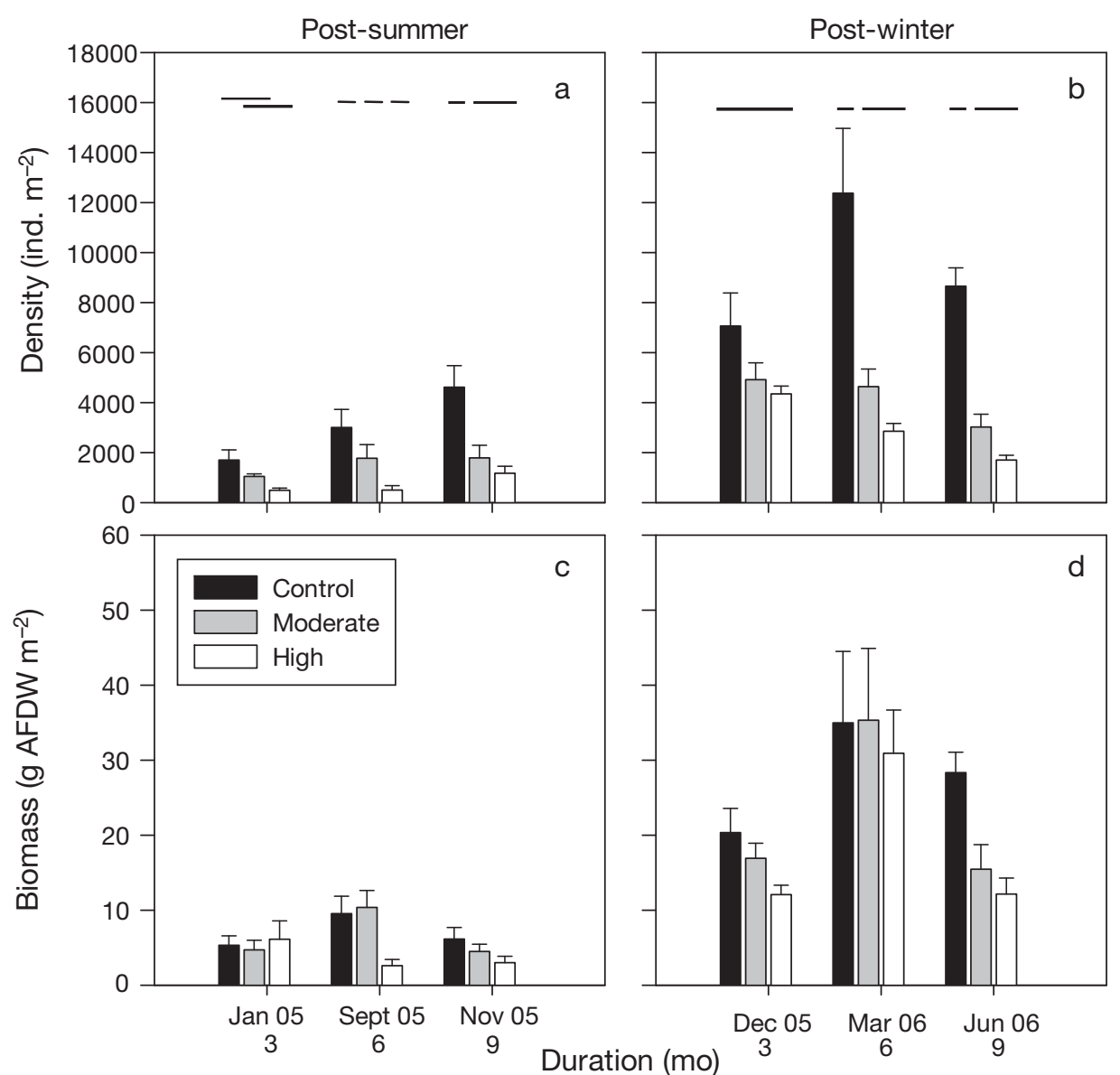

Fig. 1. Mean $(+\mathrm{SE})(\mathrm{a}, \mathrm{b})$ density and $(\mathrm{c}, \mathrm{d})$ biomass of epifauna following shading treatments of differing intensity (I, control, moderate and high), duration (D, 3, 6 and $9 \mathrm{mo}$ ) and time ( $\mathrm{T}$, post-summer and post-winter). Unbroken or shared horizontal lines across the top of bars indicate no significant difference between treatments where a $\mathrm{D} \times \mathrm{I}$ interaction has occurred (3-way ANOVA, $p<0.05$ ). Dates indicate time of sample collection. $\mathrm{n}=5$ for each $\mathrm{T} \times$ $\mathrm{D} \times \mathrm{I}$ combination

high and moderate treatments had larger specimens than the control treatments for example. Conversely, small organisms still dominated density after 9 mo, but biomass was more evenly distributed across the range of size classes (Fig. 2e-h), due primarily to a loss of biomass in larger size fractions over time.

\section{Key taxa response to shading treatments}

All of the taxa groups (gastropods, amphipods, isopods, ostracods and bivalves) responded negatively to time, duration and intensity of light reduction, although the magnitude and consistency of the responses varied. In both time treatments, gastropod density was significantly lower in the high intensity shading treatments than controls at 3 mo (by $~ 90 \%$ post-summer and $\sim 65 \%$ post-winter; Fig. 3a,b). There was a comparable effect by 6 mo in moderate shading treatments. There was also a large difference in the total number of gastropods between times, with postwinter having significantly higher densities than postsummer. The effect of any 1 factor was highly dependent on the other $2(\mathrm{~T} \times \mathrm{D} \times \mathrm{I}, \mathrm{p}<0.05$ : Table 2$)$.
Amphipods accounted for 20 to $60 \%$ of the total assemblage density and declined significantly in shaded plots relative to control treatments, though the effect of intensity and duration both depended on the time of shading. Post-hoc testing indicated that moderate treatments had fewer amphipods than control treatments, and high treatments had fewer amphipods than moderate treatments. Amphipod density in both moderate and high intensity treatments was significantly lower than in controls after $3 \mathrm{mo}$; however, this occurred in both moderate and high intensity shading treatments (rather than just high). The difference in density between moderate and high intensity treatments was greatest at 3 and 6 mo post-summer, but by 9 mo there was little difference.

For both time treatments, there was no difference in isopod density between the control treatments and either moderate and high intensity shaded treatments at $3 \mathrm{mo}$; however, isopod densities in both shaded treatments were significantly lower than the control treatment at 6 and 9 mo, although not different to each other (Fig. 3e,f). All 3 factors had an effect on isopod density, but the effect of intensity was dependent on duration of shading $(\mathrm{D} \times \mathrm{I}, \mathrm{p}<0.05$ : Table 2$)$. 
Table 2. Results of 3-way ANOVA, testing for significant effects of Time (T), Duration (D) and Intensity (I) of shading on densities and biomass of epifauna (total and separated into the 5 main taxa groups) in Amphibolis griffithii habitat. Bold $\mathrm{p}$-values represent a significant result $(\mathrm{p}<0.05)$

\begin{tabular}{|c|c|c|c|c|}
\hline & $\mathrm{df}$ & MS & $F$ & $\mathrm{p}$ \\
\hline \multicolumn{5}{|c|}{ Total biomass } \\
\hline Time & 1 & 52.17 & 129.1 & 0.001 \\
\hline Duration & 2 & 2.293 & 5.675 & 0.005 \\
\hline Intensity & 2 & 3.528 & 8.731 & 0.001 \\
\hline $\mathrm{T} \times \mathrm{D}$ & 2 & 0.252 & 0.623 & 0.539 \\
\hline $\mathrm{T} \times \mathrm{I}$ & 2 & 0.609 & 1.507 & 0.228 \\
\hline $\mathrm{D} \times \mathrm{I}$ & 4 & 0.287 & 0.709 & 0.588 \\
\hline $\mathrm{T} \times \mathrm{D} \times \mathrm{I}$ & 4 & 0.535 & 1.324 & 0.269 \\
\hline \multicolumn{5}{|c|}{ Total density } \\
\hline Time & 1 & 31.68 & 150.8 & 0.001 \\
\hline Duration & 2 & 0.192 & 0.914 & 0.406 \\
\hline Intensity & 2 & 11.72 & 55.77 & 0.001 \\
\hline $\mathrm{T} \times \mathrm{D}$ & 2 & 2.228 & 10.60 & 0.001 \\
\hline $\mathrm{T} \times \mathrm{I}$ & 2 & 0.185 & 0.881 & 0.419 \\
\hline $\mathrm{D} \times \mathrm{I}$ & 4 & 0.700 & 3.333 & 0.001 \\
\hline $\mathrm{T} \times \mathrm{D} \times \mathrm{I}$ & 4 & 0.151 & 0.717 & 0.583 \\
\hline \multicolumn{5}{|c|}{ Gastropod density } \\
\hline Time & 1 & 34.23 & 196.0 & 0.001 \\
\hline Duration & 2 & 0.367 & 2.100 & 0.130 \\
\hline Intensity & 2 & 10.86 & 62.18 & 0.001 \\
\hline $\mathrm{T} \times \mathrm{D}$ & 2 & 0.304 & 1.742 & 0.182 \\
\hline $\mathrm{T} \times \mathrm{I}$ & 2 & 0.984 & 5.637 & 0.005 \\
\hline $\mathrm{D} \times \mathrm{I}$ & 4 & 0.316 & 1.811 & 0.136 \\
\hline $\mathrm{T} \times \mathrm{D} \times \mathrm{I}$ & 4 & 0.454 & 2.598 & 0.043 \\
\hline \multicolumn{5}{|c|}{ Isopod density } \\
\hline Time & 1 & 11.60 & 60.51 & 0.001 \\
\hline Duration & 2 & 0.712 & 3.712 & 0.029 \\
\hline Intensity & 2 & 4.259 & 22.21 & 0.001 \\
\hline $\mathrm{T} \times \mathrm{D}$ & 2 & 0.130 & 0.678 & 0.511 \\
\hline $\mathrm{T} \times \mathrm{I}$ & 2 & 0.105 & 0.550 & 0.580 \\
\hline $\mathrm{D} \times \mathrm{I}$ & 4 & 0.618 & 3.225 & 0.017 \\
\hline $\mathrm{T} \times \mathrm{D} \times \mathrm{I}$ & 4 & 0.002 & 0.012 & 1.000 \\
\hline \multicolumn{5}{|c|}{ Ostracod density } \\
\hline Time & 1 & 30.08 & 57.67 & 0.001 \\
\hline Duration & 2 & 4.164 & 7.983 & 0.001 \\
\hline Intensity & 2 & 12.68 & 24.31 & 0.001 \\
\hline $\mathrm{T} \times \mathrm{D}$ & 2 & 5.836 & 11.19 & 0.001 \\
\hline $\mathrm{T} \times \mathrm{I}$ & 2 & 0.693 & 1.329 & 0.271 \\
\hline $\mathrm{D} \times \mathrm{I}$ & 4 & 1.564 & 2.998 & 0.024 \\
\hline $\mathrm{T} \times \mathrm{D} \times \mathrm{I}$ & 4 & 1.170 & 2.243 & 0.073 \\
\hline \multicolumn{5}{|c|}{ Amphipod density } \\
\hline Time & 1 & 13.44 & 28.60 & 0.001 \\
\hline Duration & 2 & 0.92 & 1.96 & 0.149 \\
\hline Intensity & 2 & 11.77 & 25.05 & 0.001 \\
\hline $\mathrm{T} \times \mathrm{D}$ & 2 & 16.35 & 34.81 & 0.001 \\
\hline $\mathrm{T} \times \mathrm{I}$ & 2 & 1.21 & 2.57 & 0.083 \\
\hline $\mathrm{D} \times \mathrm{I}$ & 4 & 0.37 & 0.79 & 0.534 \\
\hline $\mathrm{T} \times \mathrm{D} \times \mathrm{I}$ & 4 & 0.30 & 0.64 & 0.638 \\
\hline \multicolumn{5}{|c|}{ Bivalve density } \\
\hline Time & 1 & 24.17 & 145.2 & 0.001 \\
\hline Duration & 2 & 1.066 & 6.402 & 0.003 \\
\hline Intensity & 2 & 0.684 & 4.110 & 0.020 \\
\hline $\mathrm{T} \times \mathrm{D}$ & 2 & 0.982 & 5.900 & 0.004 \\
\hline $\mathrm{T} \times \mathrm{I}$ & 2 & 1.139 & 6.843 & 0.002 \\
\hline $\mathrm{D} \times \mathrm{I}$ & 4 & 0.277 & 1.665 & 0.167 \\
\hline $\mathrm{T} \times \mathrm{D} \times \mathrm{I}$ & 4 & 0.348 & 2.092 & 0.091 \\
\hline
\end{tabular}

Ostracod densities varied in response to moderate shading treatments, but were significantly lower than controls in all high intensity treatments, except for 3 mo post-winter (ANOVA, p < 0.05: Table 2). Postsummer, there was no difference between moderate and control treatment densities at $3 \mathrm{mo}$, a large difference at 6 mo (87\% less), but no difference at 9 mo (Fig. $3 g, h$ ). Post-winter there was no difference at 3 and $6 \mathrm{mo}$, but a large difference ( 60\% fewer) at 9 mo.

Bivalve densities displayed 2 distinct patterns at the 2 times, reflecting a Time $\times$ Intensity interaction (ANOVA, p < 0.05: Table 2). Post-summer, high intensity treatments had significantly lower densities than control treatments (from $58 \%$ less at 3 mo to $89 \%$ less at $6 \mathrm{mo}$ ), yet there was no difference detected between moderate intensity treatments and the control or the high intensity treatments (Fig. 3i,j). Post-winter, there was no difference between any of the intensities at any of the durations. The overall density of bivalves postwinter was much greater than post-summer.

\section{Association of epifauna with changes in seagrass habitat}

Step-wise multiple linear regressions (Table 3) indicated that both leaf biomass and the number of stems with leaves had a significant positive association with post-summer total epifaunal density, with leaf biomass the most important (normalized beta $=8.05$; Table 3 ). Post-winter, the number of leaf clusters was significantly associated with epifauna densities.

For the different key taxa, densities were significantly associated with a variety of habitat variables representing both structural complexity and potential food sources. However, there were few consistent associations between time treatments for any of the taxa (Table 3). Gastropod densities were significantly associated with algal biomass in post-summer treatments, and the number of leaf clusters in post-winter treatments. Amphipod density was strongly associated with leaf biomass and, to a lesser extent, the number of stems with leaves post-summer; amphipod density was associated with the number of leaf clusters in postwinter treatments. Isopod density had no significant association with any of the habitat variables measured post-summer, but was significantly associated with the number of stems with leaves in post-winter. Likewise, for ostracods there were no significant associations between density and any habitat variables post-summer, but there was a significant association with the number of leaf clusters and algal biomass post-winter. In contrast, bivalves were significantly associated with algal biomass and stem biomass post-summer, yet there were no significant associations post-winter. 


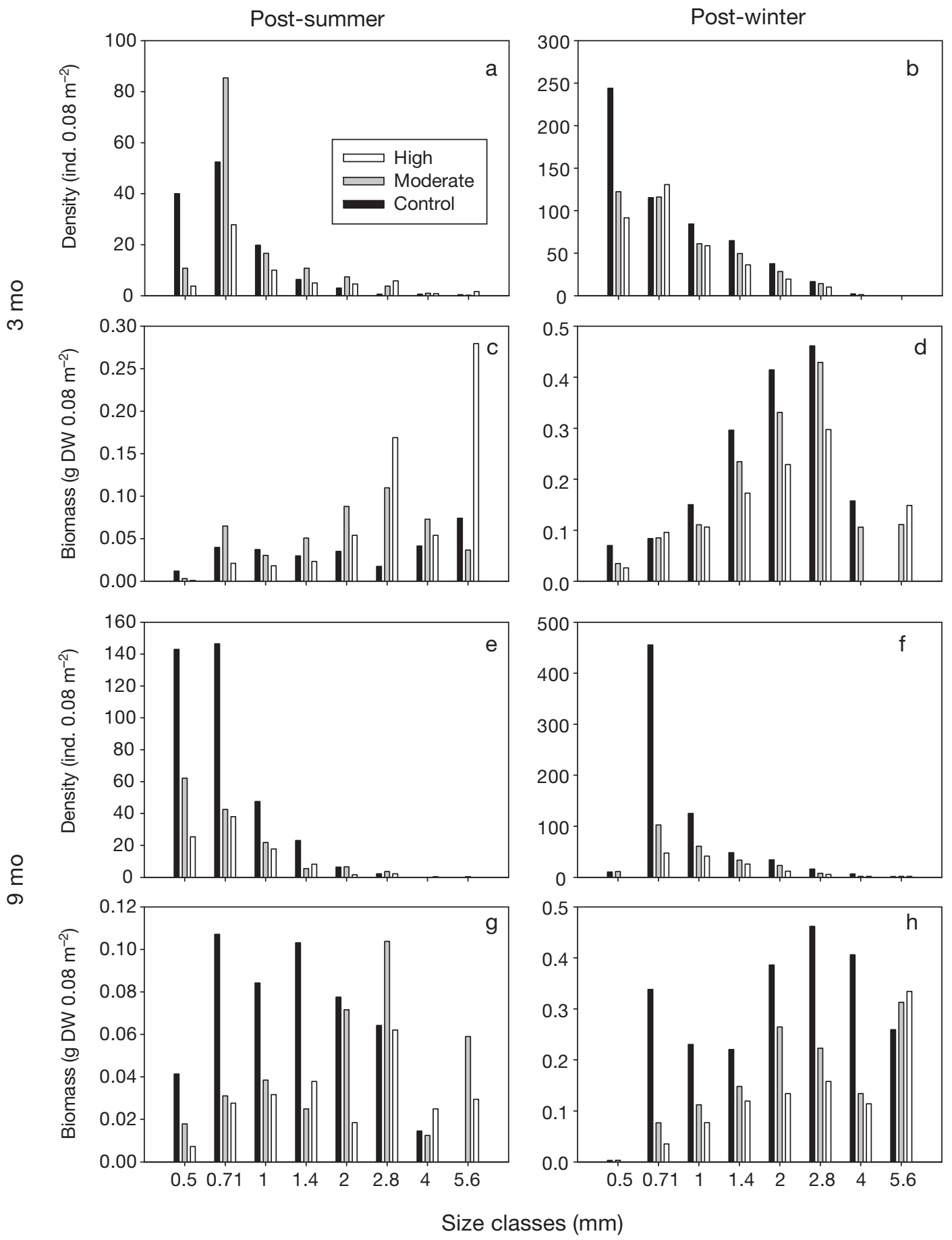

Fig. 2. Mean total epifauna $(\mathrm{a}, \mathrm{b}, \mathrm{e}, \mathrm{f})$ density and $(\mathrm{c}, \mathrm{d}, \mathrm{g}, \mathrm{h})$ biomass at $(\mathrm{a}-\mathrm{d}) 3$ mo and $(\mathrm{e}-\mathrm{h}) 9$ mo following shading treatments of differing intensity (control, moderate and high), and time (post-summer and post-winter), for each fauna size class. $\mathrm{n}=5$ for all samples. Note different scales of $y$-axis

\section{Epifauna response to changes in structural complexity}

Manipulation of the seagrass structural complexity (number of leaves and algal epiphyte biomass) confirmed a significant effect of structural complexity on the fauna assemblage (Fig. 4). In seagrass treatments with reduced structural complexity, there total epifauna density was significantly lower than in the controls (1-way ANOVA, p < 0.05: Table 4). There were $\sim 53 \%$ fewer organisms in the reduced complexity treatment (6 leaf clusters and $\sim 50 \%$ of algal epiphyte 

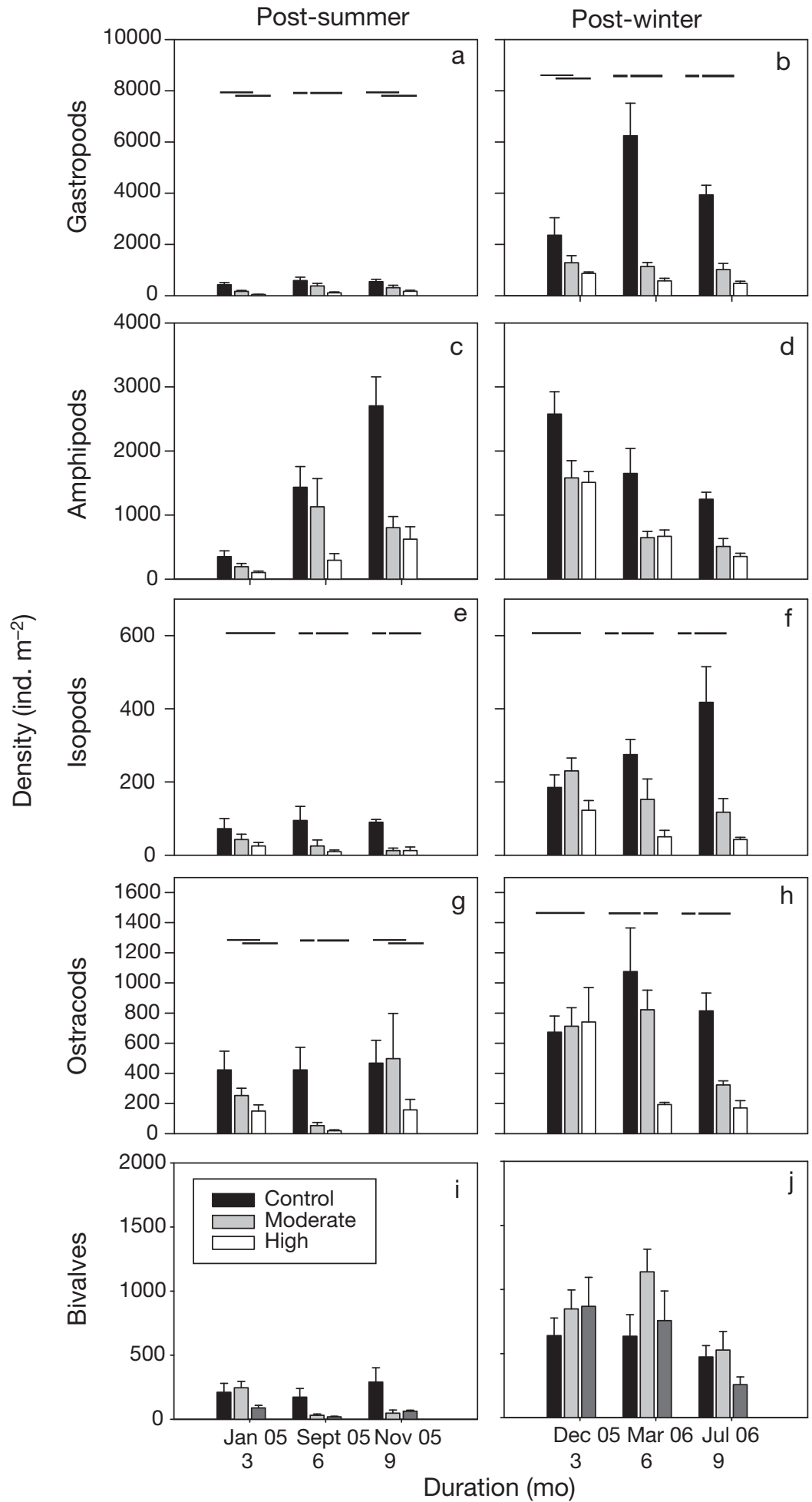

Fig. 3. Mean (+SE) density of $(\mathrm{a}, \mathrm{b})$ gastropods, $(\mathrm{c}, \mathrm{d})$ amphipods, $(\mathrm{e}, \mathrm{f})$ isopods, $(g, h)$ ostracods and $(i, j)$ bivalves following shading treatments of differing intensity (I, control, moderate and high), duration (D, 3, 6 and $9 \mathrm{mo}$ ) and time (T, postsummer and post-winter). Unbroken or shared horizontal lines across the top of bars indicate no significant difference between treatments where a $\mathrm{D} \times \mathrm{I}$ interaction has occurred ( 3 -way ANOVA, $\mathrm{p}<0.05$ ). Dates indicate time of sample collection. $\mathrm{n}=5$ for each $\mathrm{T} \times \mathrm{D} \times \mathrm{I}$ combination biomass removed per stem: Fig. 4). The procedural control (where structure was maintained, but seagrass agitated) was not significantly different to the control (1-way ANOVA, p > 0.05).

\section{Epifaunal response to predation pressure}

There was no significant effect of caging (removing predation) or shade cloth (which had associated increase in fish abundance) on total epifaunal abundance (2-way ANOVA, p > 0.05; Table 4). This outcome was observed for all classes of taxa, with the exception of gastropods, where a significant effect of the shade cloth treatment was found (Fig. 5). The mean number of gastropods was greater in the control treatments without shade cloths. However, there was no difference among cage treatments within each shading treatment, indicating that the exclusion of the predators had no effect on abundance.

\section{DISCUSSION}

\section{Overall assemblage response}

The effects of light reduction in altering the biomass and morphology of Amphibolis griffithii canopies clearly lead to significant declines in the density and biomass of the epifauna assemblage. The light reduction treatments in the shading experiment induced large losses of seagrass leaves and algal biomass. Given previous demonstrations of the dependence of epifauna on seagrass and algae for habitat (Edgar \& Robertson 1992, Sirota \& Hovel 2006), food (Bologna \& Heck 1999) and protection from predation (Heck \& Orth 2006), the negative effects on fauna were not unexpected. However, the uniqueness of the present study is that it has examined these changes in relation to different light reduction intensities, durations and times; the interactions between these factors highlight that they are not independent. For 
Table 3. Results of forward stepwise multiple linear regressions on total assemblage, gastropod, amphipod, isopod, ostracod and bivalve densities and seagrass habitat variables at 9 mo, post-summer and post-winter treatments. Only significant associations are presented $(p<0.05)$. Summer: Isopod density, Ostracod density; winter: Bivalve density had no significant association. $\mathrm{n}=15$ in all cases

\begin{tabular}{|c|c|c|c|c|c|}
\hline & Beta & SE of Beta & B & SE of B & $\mathrm{p}$ \\
\hline \multicolumn{6}{|c|}{ Summer (9 mo) } \\
\hline \multicolumn{6}{|c|}{ Total density (adjusted $\mathrm{R}^{2}=0.77482407 \mathrm{p}=0.000190$ ) } \\
\hline Leaf biomass & 8.05 & 1.68 & 242.23 & 50.52 & $<0.01$ \\
\hline No. of stems with leaves & 0.48 & 0.15 & 7.89 & 2.47 & 0.01 \\
\hline \multicolumn{6}{|c|}{ Gastropod density (adjusted $R^{2}=0.50386441 \mathrm{p}=0.001823$ ) } \\
\hline Algal epiphyte biomass & 0.73 & 0.19 & 2.92 & 0.75 & $<0.01$ \\
\hline \multicolumn{6}{|c|}{ Amphipod density (adjusted $\mathrm{R}^{2}=0.80042568 \mathrm{p}=0.000311$ ) } \\
\hline Leaf biomass & 6.43 & 1.69 & 112.58 & 29.62 & $<0.01$ \\
\hline No. of stems with leaves & 0.42 & 0.16 & 4.01 & 1.53 & 0.03 \\
\hline \multicolumn{6}{|c|}{ Bivalve density (adjusted $R^{2}=0.61761729 p=0.003269$ ) } \\
\hline Algal epiphyte biomass & 1.22 & 0.26 & 3.79 & 0.80 & $<0.01$ \\
\hline Stem biomass & 1.03 & 0.34 & 4.42 & 1.45 & 0.01 \\
\hline \multicolumn{6}{|c|}{ Winter (9 mo) } \\
\hline \multicolumn{6}{|c|}{ Total density (adjusted $\mathrm{R}^{2}=0.84009776 \mathrm{p}=0.000007$ ) } \\
\hline No. of leaf clusters & 1.70 & 0.42 & 9.01 & 2.20 & $<0.01$ \\
\hline \multicolumn{6}{|c|}{ Gastropod density (adjusted $\mathrm{R}^{2}=0.84751526 \mathrm{p}=0.000084$ ) } \\
\hline No. of leaf clusters & 1.28 & 0.56 & 3.05 & 1.33 & 0.05 \\
\hline \multicolumn{6}{|c|}{ Amphipod density (adjusted $\mathrm{R}^{2}=0.71300135 \mathrm{p}=0.000222$ ) } \\
\hline No. of leaf clusters & 1.65 & 0.51 & 1.07 & 0.33 & 0.01 \\
\hline \multicolumn{6}{|c|}{ Isopod density (adjusted $\mathrm{R}^{2}=0.70833239 \mathrm{p}=0.000244$ ) } \\
\hline No. of stems with leaves & 0.61 & 0.19 & 1.93 & 0.59 & 0.01 \\
\hline \multicolumn{6}{|c|}{ Ostracod density (adjusted $R^{2}=0.88210513 p=0.000024$ ) } \\
\hline No. of leaf clusters & 2.95 & 0.46 & 1.37 & 0.22 & $<0.01$ \\
\hline Algal epiphyte biomass & 0.55 & 0.19 & 3.46 & 1.18 & 0.02 \\
\hline
\end{tabular}

Table 4. Results of ANOVA for caging and structural complexity reduction experiments. The caging experiment tested for differences among 2 main factors, Shade Cloth (present or absent) and Caging (cage closed, cage open and open), on epifaunal densities. The structural complexity reduction experiment tested for differences in epifauna density among reduced seagrass structure treatments (reduced structure, procedural control and control). Bold $p$-value represents a significant result $(\mathrm{p}<0.05)$

\begin{tabular}{|lrrrrr|}
\hline & df & SS & MS & $F$ & $\mathrm{p}$ \\
\hline $\begin{array}{l}\text { Caging experiment } \\
\text { Total density }\end{array}$ & & & & & \\
Shade cloth & 1 & 199290 & 199290 & 1.560 & 0.228 \\
Caging & 2 & 386337 & 193169 & 1.512 & 0.247 \\
Shade cloth $\times$ Caging & 2 & 163550 & 81775 & 0.640 & 0.539 \\
& & & & & \\
Gastropod density & 1 & 1.3287 & 1.3287 & 12.39 & $\mathbf{0 . 0 0 2}$ \\
Shade cloth & 2 & 0.7228 & 0.3614 & 3.37 & 0.057 \\
Caging & 2 & 0.0537 & 0.0269 & 0.25 & 0.781 \\
Shade cloth $\times$ Caging & & & & & \\
Structural complexity reduction experiment & & \\
Reduced structure & 2 & 1.058 & 0.5292 & 5.018 & 0.031 \\
\hline
\end{tabular}

example, although intensity of light reduction had a significant effect, it appears that light intensity is less critical than the duration of light reductions. This may reflect the fact that both 'high' and 'moderate' light reduction were severe, both being more than $80 \%$ reduction of ambient PPFD, as both induced significant effects on the seagrass (Lavery et al. 2009).

The effect of duration of light reduction also appeared to be dependent on the timing of the initiation of light reduction, with trends at 3 and 6 mo differing between treatments that were initiated either post-summer or postwinter. These results reflect changes to the seagrass and algal epiphyte canopy, which responded contrary to predicted patterns (Lavery et al. 2009). It was expected that epifauna would take longer to respond to post-summer treatments (than post-winter) due to the potentially increased capacity of seagrasses to withstand light reductions at this time (Carruthers \& Walker 1997). However, the opposite response occurred, with no loss of leaf biomass after 3 mo of moderate shading postwinter, compared with significant loss after the same treatment post-summer. This reflects the complex interaction of seagrass photophysiology with temperature and ambient conditions at the different times (Lavery et al. 2009). Importantly here however, it con-

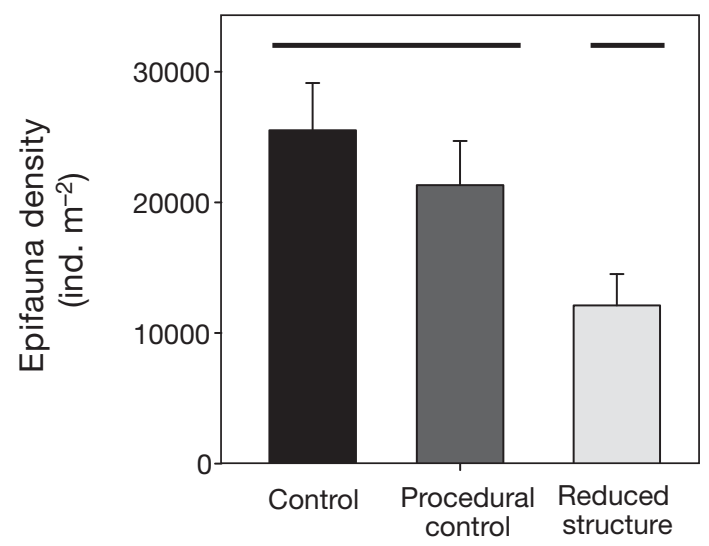

Fig. 4. Mean (+SE) total epifauna densities following structural complexity reduction treatments (control, procedural control and reduced structure) within an Amphibolis griffithii meadow. Common bars represent no significant difference between treatments $(p<0.05)$ 


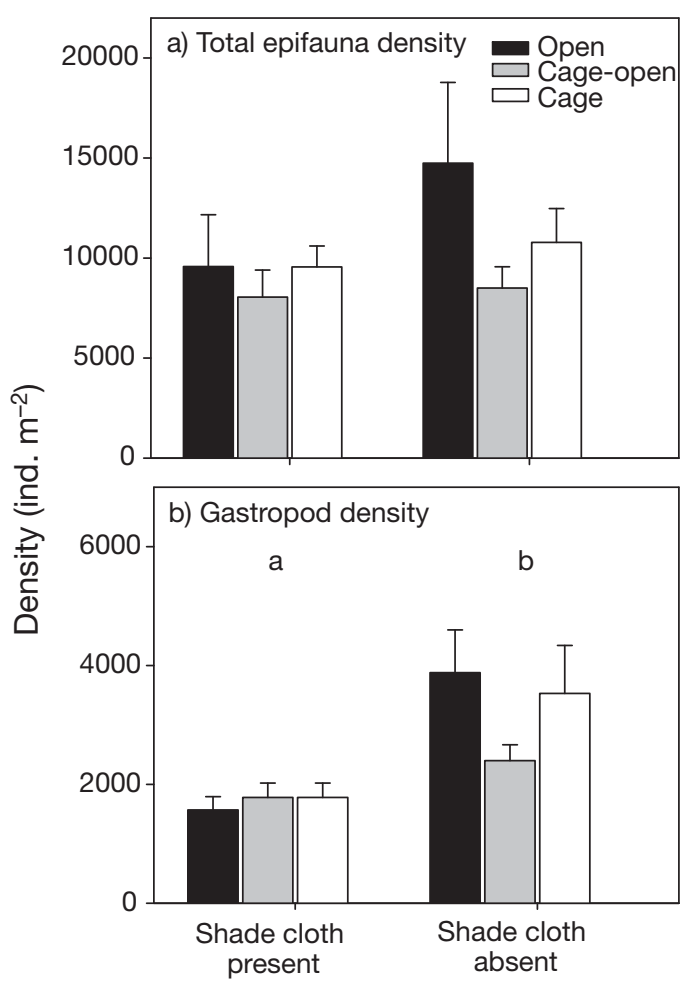

Fig. 5. Mean (+SE) (a) total density and (b) gastropod density of fauna following caging (open, cage-open and caged) and shading (shade cloth and no shade cloth) treatments. Different letters at the top of bars indicate a significant difference between shading treatments ( 2 -way ANOVA, $\mathrm{p}<0.05) . \mathrm{n}=4$

firms that fauna were responding to changes in seagrass habitat with fauna densities significantly lower post-summer after only 3 mo, while it took 6 mo for the post-winter treatments to be affected.

In the shading experiment, the 31 to $89 \%$ decline in epifauna density compared to the controls was strongly associated with losses in leaf biomass and number of leaf clusters (Table 3). This loss of fauna is likely due to reduced living space and/or fewer ecological niches (Edgar \& Robertson 1992), decline in food (Edgar 1990b) and increased exposure to predators (Sirota \& Hovel 2006). We are confident that the responses of fauna we observed reflect changes in the seagrass habitat through direct shading effects or increased predation, rather than confounding effects of the shade cloths.

The additional experiment, in which the complexity of seagrasses was manipulated, confirms that loss of structure (most likely from reduced niche-provision) explains, at least in part, the reduced epifaunal densities and that the decline was not due to the presence of the shade cloths themselves. This pattern in total density was largely driven by gastropods and amphipods. Gastropod density declined by up to $85 \%$ within 3 mo of high intensity shading in post-winter treatments, and was significantly associated with loss of algal epiphyte biomass, leaf biomass, the number of leaf clusters and the number of stems with leaves. These declines and the magnitudes of loss are consistent with other studies (Nielsen \& Lethbridge 1989, Edgar 1990b, Edgar \& Robertson 1992), where reduced gastropod and amphipod densities have been linked to declines in seagrass leaf, algal epiphyte and periphyton biomass, implying their possible reliance on these resources for food and habitat (Duffy \& Harvilicz 2001, Edgar \& Robertson 1992, Smit et al. 2005). For example, the amphipod genus Cerapus (which was common among samples) often utilizes seagrass leaves and algal material for building tubes for camouflage and protection (Lowry \& Berents 2005).

An alternative explanation for reduced epifaunal density in the shading experiment could have been increased predation pressure. Heck \& Orth (2006) have shown predation to exert a strong control on epifauna density; in the present study the number of fish under shaded treatments was almost an order of magnitude higher than in unshaded controls, and included omnivores, carnivores and invertivores. The lower faunal densities could have been due to increased predation rates (Heck \& Orth 2006), incidental ingestion by herbivorous fish (Bell \& Pollard 1989), or through a combination of both increased predator abundance and greater predator efficiency due to the loss of sheltering leaves. However, we found no difference in the density of epifauna between caged (predator excluded) and uncaged treatments under the shade cloths, thus dismissing the first 2 hypotheses. The third hypothesis, increased effective predation due to loss of structure, was not tested in this study; however, Edgar \& Robertson (1992) found no differences in epifauna abundance in a caging experiment examining the effect of predation on seagrass fauna within reduced density seagrasses. This supports the hypothesis that declines in seagrass structure from light reduction affect epifauna through the loss of habitat and food. While there exist various mechanisms of light reduction (e.g. eutrophication, turbidity, shading from structures), all ultimately lead to a reduction in seagrass from press perturbations.

In the present study, in the absence of food and habitat, much of the epifauna assemblage would have likely emigrated to the surrounding seagrass which still had its full algal epiphyte and seagrass leaf canopy intact. However, the spatial scales of impact would be much larger (hundreds of meters to tens of kilometers) in a typical light reduction event and many taxa would be forced to migrate long distances to undisturbed habitat, posing significant challenges. Predation effects due to decreased refuge are still to be tested. 
Trends in faunal biomass did not neatly parallel the changes which occurred with density. Although both variables declined over the course of the experiment in response to the treatments, the magnitude of change in biomass (i.e. proportion decline in the treatments versus controls) was generally lower and required more time to become apparent. This slower response related to the initial decline in predominantly smaller organisms, which had little effect on biomass. By 9 mo, however, the loss of larger epifauna was detectable in biomass. Epifaunal biomass has been used effectively in numerous studies (Edgar \& Barrett 2002), as well as in modeling (Lin et al. 2004), to help elucidate the effects of habitat change. The present study shows that a detailed understanding of the relative densities in each of the size class fractions is required to interpret changes in biomass, especially where the assemblage is weighted heavily in favor of numerous small organisms. It also indicates that timescales of effect may vary for density and biomass, and this needs to be considered when designing investigations or models.

\section{Variable responses among taxa to habitat disturbance}

Although the densities of most taxa declined in response to light reduction treatments and subsequent habitat changes, the variation in responses implies that changes in fauna assemblage structure and dominance resulting from shading will vary with the duration, intensity and timing of shading; this will have implications for trophic flows.

Declines in gastropod and amphipod densities occurred within 3 mo of the commencement of shading in the high intensity treatments, and by $6 \mathrm{mo}$ in the moderate intensity treatments. These results were not unexpected. There have been numerous studies in which these taxa declined in density when limited by food and habitat resources (Edgar 1990b, Jernakoff et al. 1996). These patterns occurred at both times, even though there was a large natural increase in density post-winter, in particular for gastropods. This is in contrast to the response in bivalve density, which also had significantly higher densities post-winter, but appeared not to be affected by the light reduction treatments at this time. Leaves, epiphytic algae and seagrass stems all form potential substrata for small canopy dwelling bivalves. Therefore, it might be expected that the loss of living space would also affect bivalve densities. This appears to be the case in the post-summer treatments, where declines in bivalve densities can be linked to corresponding declines in algal epiphyte and stem biomass (Table 3). However, it is probable that a large recruitment event occurred post-winter (see high abundance of 0.5 to $1.0 \mathrm{~mm}$ size categories, Fig. 3b), which counterbalanced effects associated with reduced living space. If bivalve taxa within the Amphibolis griffithii assemblage show some degree of year-round recruitment and reproductive potential, then it is possible to maintain abundance, even during/post disturbance, as long as a substrate (such as stems) and a food source (single cellular primary productivity) remain available. The unknown bivalve which dominated samples here was commonly found among the algal epiphytes, which we speculate provides a substrate; it is unlikely that phytoplankton availability would be affected by the experimental design, thus providing a continual food supply.

Ostracods responded inconsistently to the shading treatments, especially to the moderate treatments (Fig. 3g-h). They are considered generalist feeders (Athersuch et al. 1989), but very little is known or published on the feeding and habitat requirements of ostracods (Smith 2000). As such, the results of the present study suggest that it is very difficult to predict the impacts of moderate levels of disturbance on such taxa.

\section{Trophic implications of seagrass habitat disturbance}

For many seagrass systems, the dietary requirements of the majority of larger consumers, such as fish and decapods, are provided from the invertebrate fauna (Howard \& Edgar 1994). As much as $88 \%$ of the food consumed by seagrass fishes is estimated to be macroinvertebrates (Robertson 1984). Gastropods in particular have been linked to the diet of many higher order consumers (Joll \& Phillips 1984), and growth rates of some predatory seagrass associated species, such as the western rock lobster Panulirus cygnus, can be limited by the absence of a nutritionally rich invertebrate diet (Joll \& Phillips 1984). Despite this link, there have been very few studies which have been able to quantify the effect of seagrass loss on higher trophic orders (Gillanders 2007). However, the loss of up to $80 \%$ of first order consumers, as occurred in the present study, is likely to lead to a substantial decrease in energy flow to higher order consumers.

The results from the present study also indicate that shifts in community size structure and taxa dominance are possible. Initial $(<3 \mathrm{mo})$ declines in abundance were largely confined to small individuals $(\leq 1.4 \mathrm{~mm})$, with longer-term ( 6 to $9 \mathrm{mo}$ ) declines occurring across all size categories. We speculate that this may be because of the competitive advantage of larger individuals over smaller ones. These temporal patterns may differentially affect higher order consumers (particularly those with specialized diets that depend on those invertebrates), or force other taxa with the 
capacity to switch between resources to consume a non-preferred diet, potentially limiting productivity (Joll \& Phillips 1984). One such example is the economically important western rock lobster Panulirus cygnus, which has a preference for molluscs within the sizerange of 2.0 to $5.6 \mathrm{~mm}$ (Edgar 1990a).

Predicting the effects of the shading disturbance across the epifaunal assemblage has been shown to be complex. This was particularly apparent in moderate shading treatments where the magnitude of the effect, at least in the short term, was low and the response of some taxa, such as ostracods and bivalves, was variable. Not unexpectedly, this variability appears to decrease substantially with an increase in the level of disturbance, suggesting that few taxa within the seagrass canopy have the capacity to withstand substantial declines in seagrass habitat for much longer than a few months. It is also clear that taxa such as gastropods and amphipods, which account for most of the abundance, show consistent predictable responses linked to structural and food attributes. Thus, in the short term $(<3 \mathrm{mo})$ moderate shading may have differential consequences, but longer term ( $>3$ to $6 \mathrm{mo}$ ) or under high intensity shading ( $>90 \%$ light reduction) there are likely to be effects across all first order consumers, with consequences for higher trophic orders.

Amphibolis species have a very complex architectural structure compared to other seagrasses, with generally higher densities and diversity of epifauna associated with them (Edgar 1990b). However, general trends observed in this study (i.e. declines in epifaunal density and biomass) would also likely occur in other seagrass species under similar reduced light conditions (although timescales of decline and magnitudes of response may vary). Epifauna respond to changes in seagrass and algal epiphyte density. Therefore, it is probable that epifauna occurring within other persistent seagrasses such as Posidonia sinuosa, which respond in a consistent manner to light reductions (Collier et al. 2007), would also decline. However, the response of epifauna inhabiting seagrasses with much shorter life cycles, such as Halodule or Halophila seagrasses, are much less predictable.

\section{CONCLUSIONS}

This research has shown that the intensity, duration and time of light reduction on an Amphibolis griffithii seagrass system influences the density and biomass of epifauna. There were significant interactions between all 3 factors, and the duration of the disturbance was particularly important. Epifauna generally responded negatively to the disturbance induced by shading treatments; however, taxa-specific responses were variable in terms of the duration of shading before a response was observed and the magnitude of the response. The duration of treatments also affected the size distribution of epifauna, with smaller individuals being affected the greatest in the short-term; effects occurred across the size classes in the longer-term. Changes in epifaunal density were largely associated with declines in algal biomass, leaf canopy variables and stem biomass. Given the importance of macroinvertebrates as a food source, it would be likely that the significant declines in epifauna observed in this experiment would have flow-on consequences to higher trophic levels.

Acknowledgements. Comments and advice on this paper by G. Hyndes, A. Verges and J. Eklof are much appreciated. We are particularly grateful to numerous divers including A. Tennyson, P. Quintana and M. Mulligan for many hours of assistance with fieldwork. This research was funded by the Strategic Research Fund for the Marine Environment, Western Australian Marine Science Institute, Department of Environment and Conservation, Western Australia and the Holsworth Wildlife Research Fund.

\section{LITERATURE CITED}

Athersuch J, Horne DJ, Whittaker JE (1989) Marine and brackish water ostracods. Synop Br Fauna New Ser 43:343-351

Baden S, Gullstrom M, Lunden B, Pihl L, Rosenberg R (2003) Vanishing seagrass (Zostera marina, L.) in Swedish coastal waters. Ambio 32:374-377

Bell JD, Pollard DA (1989) Ecology of fish assemblages and fisheries associated with seagrasses. In: Larkum AWD, McComb AJ, Shepherd SA (eds) Biology of seagrasses: a treatise on the biology of seagrass with special reference to the Australian region. Elsevier, Amsterdam

Bologna PAX, Heck KL (1999) Macrofaunal associations with seagrass epiphytes - relative importance of trophic and structural characteristics. J Exp Mar Biol Ecol 242:21-39

Bostrom C, O'Brian K, Roos C, Ekebom J (2006) Environmental variables explaining structural and functional diversity of seagrass macrofauna in an archipelago landscape. J Exp Mar Biol Ecol 335:52-73

Brearley A, Wells FE (2000) Invertebrate fauna in seagrasses on Success Bank, Western Australia. Biol Mar Medit 7: 199-202

Brearley A, Kendrick AJ, Walker D (2008) How does burrowing by the isopod Limnoria agrostisa (Crustacea: Limnoriidae) affect the leaf canopy of the southern Australian seagrass Amphibolis griffithii? Mar Biol 156:65-77

> Cabello-Pasini A, Lara-Turrent C, Zimmerman RC (2002) Effect of storms on photosynthesis, carbohydrate content and survival of eelgrass populations from a coastal lagoon and the adjacent open ocean. Aquat Bot 74:149-164

> Carruthers TJB, Walker DI (1997) Light climate and energy flow in the seagrass canopy of Amphibolis griffithii (J. M. Black) den Hartog. Oecologia 109:335-341

Carruthers TJB, Longstaff BJ, Dennison WC, Abal EG, Aioi K (2001) Measurement of light penetration in relation to seagrass. In: Short F, Coles R (eds) Global seagrass research methods. Elsevier, Amsterdam, p 369-392 
Collier CJ, Lavery PS, Masini RJ, Ralph PJ (2007) Morphological, growth and meadow characteristics of the seagrass Posidonia sinuosa along a depth-related gradient of light availability. Mar Ecol Prog Ser 337:103-115

Duffy JE, Harvilicz AM (2001) Species-specific impacts of grazing, amphipods in an eelgrass-bed community. Mar Ecol Prog Ser 223:201-211

Edgar G (1990a) Predator-prey interactions in seagrass beds. I. The influences of macrofaunal abundance and size-structure on the diet and growth of the western rock lobster Panulirus cygnus George. J Exp Mar Biol Ecol 139:1-22

Edgar GJ (1990b) The influence of plant structure on the species richness biomass and secondary production of macrofaunal assemblages associated with Western Australian seagrass beds. J Exp Mar Biol Ecol 137:215-240

Edgar GJ (1990c) The use of the size structure of benthic macrofaunal communities to estimate faunal biomass and secondary production. J Exp Mar Biol Ecol 137: 195-214

Edgar GJ, Barrett NS (2002) Benthic macrofauna in Tasmanian estuaries: scales of distribution and relationships with environmental variables. J Exp Mar Biol Ecol 270:1-24

Edgar GJ, Robertson AI (1992) The influence of seagrass structure on the distribution and abundance of mobile epifauna-pattern and process in a Western-Australian Amphibolis bed. J Exp Mar Biol Ecol 160:13-31

EPA (2001) Turquoise coast development, Jurien Bay. Ardross Estates Pty. Ltd., Environmental Protection Authority, Perth, Western Australia

EPA (2002) Geraldton port enhancement project and preparatory works for the town beach foreshore redevelopment. Geraldton Port Authority, Environmental Protection Authority, Perth, Western Australia

Erftemeijer PLA (2006) Managing the effects of dredging on seagrasses in the Mediterranean Sea. Biol Mar Medit 13: $183-188$

Field A (2005) Discovering statistics using SPSS (and sex, drugs and rock ' $n$ ' roll). Sage, London

Gillanders BM (2007) Seagrass. In: Connell SD, Gillanders BM (eds) Marine ecology. Oxford University Press, Melbourne, p 457-485

Heck KL, Orth RJ (2006) Predation in seagrass meadows. In: Larkum AWD, Orth RJ, Duarte CM (eds) Seagrass biology: a treatise. Kluwer, Amsterdam, p 1-13

Holloway K (2006) Characterizing the hydrodynamics of Jurien Bay, Western Australia. The University of Western Australia, Perth

Howard RK, Edgar GJ (1994) Seagrass meadows. In: Hammond LS, Synnot RN (eds) Marine biology. Longman Cheshire, Melbourne, p 257-271

- Jernakoff P, Nielsen J (1997) The relative importance of amphipod and gastropod grazers in Posidonia sinuosa meadows. Aquat Bot 56:183-202

Jernakoff P, Brearley A, Nielsen J (1996) Factors affecting grazer-epiphyte interactions in temperate seagrass meadows. Oceanogr Mar Biol Annu Rev 34:109-162

Joll LM, Phillips BE (1984) Natural diet and growth of juvenile western rock lobsters Panulirus cygnus George. J Exp Mar Biol Ecol 75:145-169

Klumpp DW, Howard RK, Pollard DA (1989) Trophodynamics and nutritional ecology of seagrass communities. In: Larkum AWD, McComb AJ, Shepherd SA (eds) Biology of seagrasses: a treatise on the biology of seagrasses with

Editorial responsibility: Hans Heinrich Janssen, Oldendorf/Luhe, Germany special references to the Australian region. Elsevier, Amsterdam, p 394-457

Lavery PS, McMahon K, Mulligan M, Tennyson A (2009) Interactive effects of timing, intensity and duration of experimental shading on Amphibolis griffithii. Mar Ecol Prog Ser 394:21-33

Lin H, Shao K, Hwang J, Lo W, Cheng I, Lee L (2004) A trophic model for Kuosheng Bay in Northern Taiwan. J Mar Sci Technol 12:424-432

Longstaff BJ, Dennison WC (1999) Seagrass survival during pulsed turbidity events: the effects of light deprivation on the seagrasses Halodule pinifolia and Halophila ovalis. Aquat Bot 65:105-121

- Lowry JK, Berents PB (2005) Algal-tube dwelling amphipods in the genus Cerapus from Australia and Papua New Guinea (Crustacea: Amphipoda: Ischyroceridae). Rec Aust Mus 57:153-164

McMahon K, Lavery P (2008) The responses of Amphibolis griffithii to reduced light availability. Final report on the Strategic Research Fund for the Marine Environment (SRFME) Collaborative Research Project: ecophysiology of benthic primary producers. Centre for Marine Ecosystems Research, Edith Cowan University, Joondalup, Western Australia

Nielsen J, Lethbridge R (1989) Feeding and the epiphyte food resource of gastropods living on the leaves of the seagrass Amphibolis griffithii in southwestern Australia. Malacol Soc Aust 10:47-58

Orth RJ, Carruthers TJB, Dennison WC, Duarte CM and others (2006) A global crisis for seagrass ecosystems. Bioscience 56:987-996

Quinn GP, Keough MJ (2002) Experimental design and data analysis for biologists. Cambridge University Press, Cambridge

Robertson AI (1984) Trophic interactions between the fish and macrobenthos of an eelgrass community in Westernport Bay, Victoria. Aquat Bot 18:135-153

Ruiz JM, Romero J (2001) Effects of in situ experimental shading on the Mediterranean seagrass Posidonia oceanica. Mar Ecol Prog Ser 215:107-120

Sheridan P (2004) Recovery of floral and faunal communities after placement of dredged material on seagrasses in Laguna Madre, Texas. Estuar Coast Shelf Sci 59:441-458

Short FT, Wyllie Echeverria S (1996) Natural and humaninduced disturbance of seagrasses. Environ Conserv 23: $17-27$

Sirota L, Hovel KA (2006) Simulated eelgrass Zostera marina structural complexity: effects of shoot length, shoot density, and surface area on the epifaunal community of San Diego Bay, California, USA. Mar Ecol Prog Ser 326: 115-131

> Smit AJ, Brearley A, Hyndes GA, Lavery PS, Walker DI (2005) Carbon and nitrogen isotope analysis of an Amphibolis griffithii seagrass bed. Estuar Coast Shelf Sci 65:545-556

Smith RJ (2000) The morphology of the upper lip of Cypridoidea ostracods: taxonomic and phylogenetic significance. Hydrobiologia 418:169-184

West RJ (1990) Depth-related structural and morphological variations in an Australian Posidonia seagrass bed. Aquat Bot 36:153-166

Zar JH (1999) Biostatistical analysis. Prentice Hall International, Upper Saddle River, NJ

Submitted: December 19, 2009; Accepted: October 12, 2009 Proofs received from author(s): February 15, 2010 